\title{
Online English Teaching Based on Artificial Intelligence Internet Technology Embedded System
}

\author{
Haidong Ban $(\mathbb{D})$ and Jing Ning $(\mathbb{C}$ \\ College of Humanities and Education, Xijing University, Xi'an 710123, Shaanxi, China \\ Correspondence should be addressed to Haidong Ban; 20150124@xijing.edu.cn
}

Received 26 August 2021; Revised 13 October 2021; Accepted 19 October 2021; Published 13 November 2021

Academic Editor: Sang-Bing Tsai

Copyright ( $) 2021$ Haidong Ban and Jing Ning. This is an open access article distributed under the Creative Commons Attribution License, which permits unrestricted use, distribution, and reproduction in any medium, provided the original work is properly cited.

\begin{abstract}
With education and teaching reform, Internet teaching is increasing. The introduction analysis of short text messages generated by e-learning can optimise class, improving innovation capacity and cooperation. To study the way of instructional design under artificial intelligence, the current status of the development of instructional has to be mentioned. In order to study the impact of online teaching on the improvement of computer thinking and skills in higher vocational education, this article is based on online English teaching embedded in the Internet and on virtual simulation technology, to enable primary school students to cultivate computer education thinking from an early age. The personalities can be fully represented and developed.
\end{abstract}

\section{Introduction}

It has brought mankind into the age with intelligence ahead of schedule. Series of policy documents related to AI education provide strategic support. The creative culture industry is entering into the development stage. As the creative industry puts demands on internal digital art education, the development of a well-suited path for digital artefact education is necessary to be studied [1]. Under the requirements of the creative cultural industry, our country has explored a new model of digital art talent training, combining talent training with industry interaction and realizing the road of combining production. Students' social adaptability and students suitable for social needs are cultivated, so that students not only master a good knowledge system but also master design skills and have moral intelligence and adaptability $[2,3]$.

It is beneficial to teach English to communicate with each other [4]. The pedagogy of using multimedia for presentation has not yet been disruptive. That teaching method is still based on teacher's teaching and cannot improve students' independent and collaborative learning ability. A traditional teaching model is still old and rigid, which places emphasis on the completion of conclusions but not the process. The online teaching mode mobilizes a variety of intelligences, so that students are interested in learning and are willing to participate in classroom activities, brainstorming, teamwork, problem-solving, and ultimately achieve the goal of improving various abilities [5]. This mode of teaching mathematics is used to improve various intelligences of students, so that each student's mathematics learning has improved. While the web-based teaching model has been widely used overseas, it has remained a new educational concept in China. It has gradually been accepted in China's education field, but some educational researchers have studied it, but diverse teaching models in the subject have been used. There are still relatively few practical research studies in [6]. Designing a network-based artificial intelligence-assisted teaching system has very important practical significance.

Donadel M promoted new online and offline teaching [7]. Basilaia $G$ drew on the implementation process of the online [8]. Vella et al. believed blended learning as a new teaching model that can complement each other [9]. Simpson A mainly effectively analyzed the student's academic performance [10].

Online English teaching instructors, namely, college teachers, and college physical education curriculum 
recipients and subjects, namely, students, together participate in the evaluation and survey system.

\section{Embedded System Online English Teaching Method}

2.1. Internet and Virtual Simulation Technology. Virtual simulation technology is an emerging science and technology developed by incorporating various computerrelated technologies and achievements, such as artificial intelligence, computer graphics, display, crawling, and parallel network processing. The environment gives people a full range of emotions such as hearing, sight, and touch $[11,12]$. As a new way for people to perform complex interactions and data computations, users can use natural methods in virtual environments. This is the biggest feature of virtual simulation technology. People can indirectly understand the environment in the past unless they rely on ways other than interaction experience to make people's cognitive domains and methods expand effectively.

It can create a sense of sinking [13]. The technologies include computer technology, multimedia technology, information technology, microelectronics technology, simulation technology, stereo imaging technology, detection and measurement technology, optical psychology, optical science, computer vision, and speech and composition recognition and interaction. The specific implementation is shown in the following formula:

$$
y\left(k T+t_{i}\right)=\frac{1}{\alpha(z)} \sum_{j=1}^{r} \beta_{i j}(z) \bar{u}\left(k T+t_{j-1}\right)+v\left(k T+t_{i}\right) .
$$

It can be transformed into the following:

$$
\begin{gathered}
\alpha(z)=1+\alpha_{1} z^{-1}+\alpha_{2} z^{-2}+\cdots+\alpha_{n} z^{-n}, \\
\beta_{i j}(z)=\beta_{i j}^{0}+\beta_{i j}^{1} z^{-1}+\beta_{i j}^{2} z^{-2}+\cdots+\beta_{i j}^{n} z^{-n} .
\end{gathered}
$$

A new transfer function model is proposed:

$$
y\left(k T+t_{t}\right)=\frac{B_{i}(\delta)}{A_{i}(\delta)} \bar{u}\left(k T+t_{i}\right)+v\left(k T+t_{i}\right) .
$$

Virtual simulation has now evolved into a comprehensive theme, such as computer graphics, real-time image processing, human-machine interface, precision inspection structure, and more. Virtual simulation technology includes two broad categories: one is virtual reality technology and the other is virtual landscape technology, such as virtual aircraft design, virtual reality environment creation, and historical monument tours [14]. Virtual simulation technology has a wide range of applications. It can be said to be extensive and comprehensive. In many areas, the technical and market demands are very strong, such as virtual film and television art simulation, virtual simulation games, virtual construction of cars, ships, airplanes, missiles, virtual battle simulation, virtual battlefield simulation, and virtual simulation driving.
An authorized person pointed out that the representative of information technology in this century is virtual simulation technology. The development of this technology has radically changed the way people live and work [15]. It really combines "work" and "comfort." People enjoy the work environment and work enjoying the environment; in addition, this technology is compatible with a combination of different cultures and arts such as music and fine arts that will promote the birth of the ninth art. Therefore, there are two major trends in the operation of virtual simulation technology systems at this stage, namely, Internet use and standalone desktops, which have greatly encouraged [16].

2.2. Online Teaching. When compared against a conventional offline classroom, there is more freedom in time and space when learning online. And it has richer types and resources for quick sharing. There are various platforms by which teachers and students have a platform and resources to conduct online learning $[17,18]$.

In secondary vocational education, as well as the principles of teaching, we must create rich learning scenarios for students when conducting teaching work and the creation of learning scenarios must be real world scenarios, so that students learning outcome will be better [19]. For this reason, we apply virtual simulation technology to the teaching of art theory courses, which is to create the best learning situation for students. In electronic technology teaching, we use virtual simulation technology to create a virtual simulation learning situation for students. Using computers to mimic real laboratory functions on the screen can make art forms, paintings, and curves difficult to express or understand in words and languages. At the same time, we can make the artwork show the real situation and help students understand [20].

Artificial intelligence provides a lot of opportunities for the development of many fields, and its important role has attracted great attention at home and abroad. Many countries have formulated policies and plans to upgrade artificial intelligence into national strategies [21, 22]. The online teaching mode is shown in Figure 1.

The rise of digital art education is not accidental [23]. As an emerging educational research direction, digital art education is primarily the cultivation of professionals who can use images and digital elements to design art. Students' ability to combine new ideas with new technologies and students' ability to use digital media are cultivated. Uniqueness and complexity of the subject of digital art are the difficult place to coordinate the management of teaching, which requires us to overturn the old ideas and concepts of the traditional school model and equip teaching with new ideas and concepts.

For the emerging educational direction of digital education, teachers must maintain their passion and expectations and be ready to dedicate themselves to theoretical research in this field of education [24]. At this stage, the alien management software in this aspect is at the forefront of development and design, and the software usage rate is very high, and the development methods are also very advanced. 


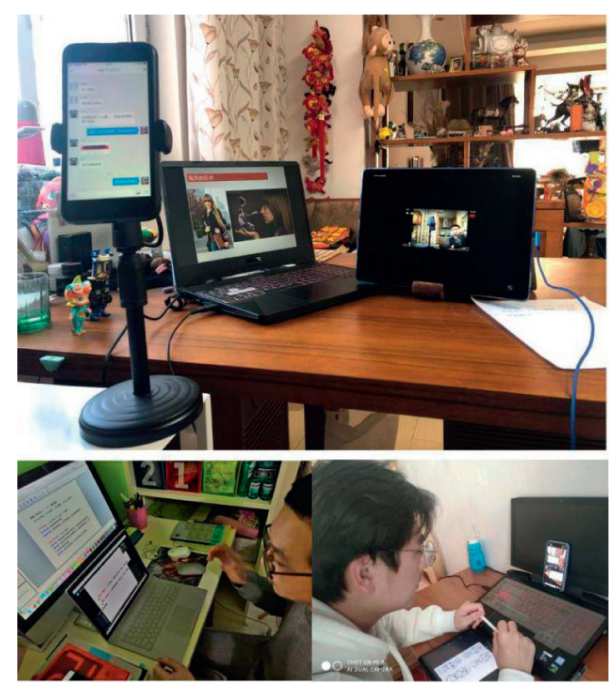

FIgURE 1: Online teaching (source: image.baidu.com).

In many developed European countries, digital art education is well developed and advanced. Due to the importance of art design in the teaching of digital art design, these countries have established new professions such as digital communication and have cultivated many digital art professionals that meet the needs of society [25].

In response to the special needs and requirements of the digital English teaching system, we have designed a learning and teaching system suitable for the interaction of both teaching parts. The exchange of information and publication can take place in this system, as well as the exchange and learning between teachers and students and pupils and students can take place. Through this new teaching system, it is possible to realize long-term and spatial communication and cooperation between college administrators, teachers, and students.

According to the different intellectual advantages of each person, we can give full play to each person's ability, mobilize students' enthusiasm for learning, stimulate students' superior intelligence, and help students shape a sound personality. Through online education, they exercise their skills and qualities in many aspects and relieve the limitations of traditional education, which can only learn specific topics and achieve quality integrated development and improvement.

2.3. Embedded Teaching Algorithm. Technology is a subject that combines theory and practice closely. So, teachers should choose cases closely related to students' school and live for teaching English online to strengthen students' understanding of IT theories and operational knowledge. It is important for teachers to learn from other disciplines to strengthen students' knowledge application, exercise their problem-solving skills, and lay the foundation for their lifelong academic. For the research and optimization of embedded teaching algorithms, we calculate using the following equation:

$$
t(s)=\exp \left(-\int_{0}^{s} \kappa(t) \mathrm{d} t\right) .
$$

From this, we can see

$$
\begin{aligned}
\partial & =1-t(s)=1-\exp \left(-\int_{0}^{s} \kappa(t) d t\right), \\
\frac{d I}{d s} & =T(s) * \rho(s) * A=T(s) * \kappa(s), \\
I(s) & =I_{0}+\int_{0}^{s} g(t) d t, \\
x(k+1) & =I x(k)+J v(k), \quad k=1,2, \ldots, \\
K & =\sum_{k=1}^{\infty}\left[x^{i}(k) J x(k)+r^{i}(k) c J\right], \\
Q & =\frac{1}{2 a^{2} r^{-1}}\left(\frac{2 b^{2}}{a^{2} r^{-1}} p-t\right)^{-1}\left[a^{2} r^{-1} t^{2}+2\left(1-b^{2}\right) t\right], \\
Q & =\frac{1}{2 a^{2} r^{-1}}\left(\frac{2 b^{2}}{a^{2} r^{-1}} t-L\right)^{-1}\left[a^{2} r^{-1} L^{2}+2\left(1-a^{2}\right) L\right], \\
\left(\frac{2 b^{2}}{a^{2} r^{-1}} I_{x}-t\right) Q & =\frac{1}{2} t^{2}+\frac{1-b^{2}}{a^{2} r^{-1}} t .
\end{aligned}
$$


TABLE 1: Mastery of male students.

\begin{tabular}{lcccccc}
\hline & Creative thinking & Learning attitude & Learning ability & Basic ability & Painting & Cultural lessons \\
\hline Class 1 & 1.83 & 1.89 & 2.4 & 2.15 & 2.35 & 1.9 \\
Class 2 & 2.42 & 2.41 & 2.23 & 2.01 & 1.99 & 1.87 \\
Class 3 & 1.92 & 2.16 & 2.42 & 2.37 & 1.88 & 2.06 \\
Class 4 & 1.85 & 2.09 & 2.25 & 1.82 & 2.15 & 2.37 \\
Class 5 & 2.1 & 2.32 & 2 & 2.41 & 1.83 \\
Class 6 & 2.11 & 1.87 & 1.85 & & 2.02 \\
\hline
\end{tabular}

The following equation can be derived from the above:

$$
Q^{2}+\frac{2\left(1+b^{2}\right)}{a^{2} r^{-1}} Q+\frac{\left(1+b^{2}\right)^{2}}{\left(a^{2} r^{-1}\right)^{2}} I_{x}=\left(Q+t+\frac{1-b^{2}}{a^{2} r^{-1}} I_{x}\right)^{2} \text {. }
$$

Excessive information cannot be equated with other problems. By monitoring teaching added to the online learning process, students can recognise their own learning outcomes at any time and improve them selectively in time.

\section{Online English Teaching Experiment}

3.1. Subject. We selected 6 classes in the arts department of a university in this city and grouped them to learn in traditional teaching mode.

3.2. System Design Principles. Both the rationality of the technology and the practicality of the technology are taken into account. According to factors such as scale and positioning of the system, combined with the rationality and practicality of technology to achieve the best cost efficiency, the technique is neither great nor very bad, suitable for the best in real time. When designing an information system, it is necessary to take full account of the security, location, scale, and interactivity of the system and the rationalization of technology to design a specific information system.

3.3. Course Management Planning. The course management module mainly includes submodules such as lesson planning, lesson presentation, lesson planning, and online teaching evaluation. Lesson design focuses on functions such as lesson planning, lesson setting, and curriculum introduction; lesson projection uses primarily 3D technology, animation effects, and artistic methods to enhance lesson content; courses mainly concern that the art school has been designed accordingly. Online teaching evaluation means that students evaluate the teacher's teaching and systematically evaluate the evaluation. Curriculum management module is the basis of teaching; a good and smooth management module can allow students to pursue university studies and live well.

3.4. Teaching Interactive Management Planning. Interact Teaching Management Module consists of five main submodules: Guidance for Teachers, Independent Learning for
Students, Groups Interactive Learning, Assessment and Promotion, and Online Q\&A. As the core module of the digital English teaching system and the core module of interactive teaching management, teachers can connect to the Internet to collect the materials they were learning and then present them to students through the web server. For students, they can also connect to the network to collect their own materials which are then shared with their students through the web server.

\section{Online English Teaching Experiment Analysis}

4.1. Student Status. According to the gender of students, mastery of them is shown in Tables 1 and 2.

As shown in Figure 2, in the six experimental classes, male students' mastery of art is basically similar, and their cultural courses, painting, and thinking skills are not much different, indicating that the selected sample data are comparative and convenient for comparison. Student changes before and after virtual reality technology. In order to comprehensively compare the data and compare the changes in the artistic abilities of students of different genders under virtual reality technology, we have drawn Table 2.

It can be seen from Figure 3 that there are some differences in overall artistic abilities between male and female students before they have been taught. Female students' thinking and learning abilities are slightly higher than those of male students, but the overall difference is not large. Basically, it does not affect the experimental results.

4.2. Degree of Improvement of Different Learning Methods. Three-month teaching is conducted for these six classes, and the students are divided into two types of teaching. After that, we calculated the students' artistic abilities and compared the changes in their abilities, as shown in Table 3.

It can be seen from Figure 4 that after three months of teaching, the score of the experimental group has not improved much; it improved only from the mean value of 2 to about 2.7, while the students who were taught through virtual reality technology have increased greatly, from the score of 2 to about 5 . In order to verify whether the conclusion is also suitable for female students, we have made statistics on the promotion of female students, as shown in Table 4.

It can be seen from Figure 5 that after ordinary teaching, female students have increased from 2 to about 3.5, and after 
TABle 2: Art mastery of female students.

\begin{tabular}{lcccccc}
\hline & Creative thinking & Learning attitude & Learning ability & Basic ability & Painting & Cultural lessons \\
\hline Class 1 & 2.38 & 2.28 & 1.84 & 1.81 & 2.21 & 2.91 \\
Class 2 & 2.16 & 2.47 & 2.23 & 2.4 & 2.28 & 1.86 \\
Class 3 & 2.22 & 1.98 & 2.27 & 2.14 & 1.98 & 2.34 \\
Class 4 & 2.24 & 1.81 & 2.05 & 1.8 & 2.5 & 1.94 \\
Class 5 & 2.25 & 1.96 & 1.84 & 2.41 & 2.29 & 2.27 \\
Class 6 & 2.46 & 1.87 & 1.99 & & & 2.09 \\
\hline
\end{tabular}

2.7
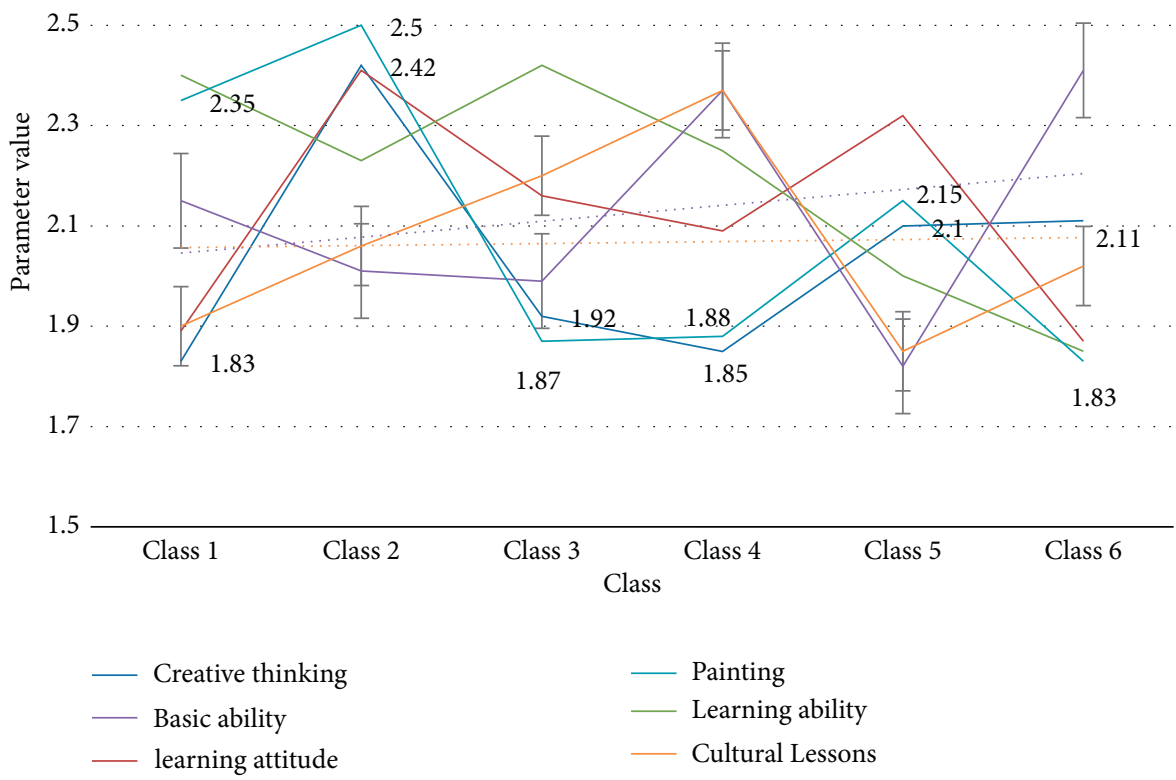

Figure 2: Art mastery of male students.

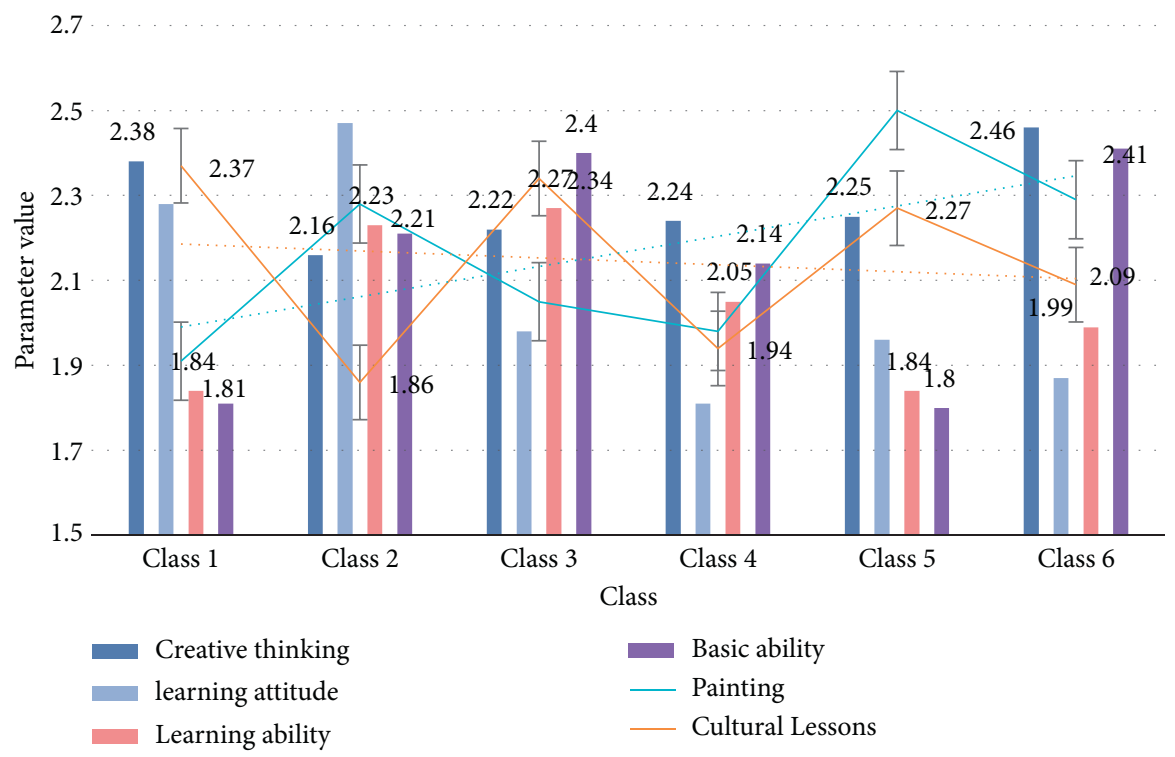

FIGURE 3: Female students' mastery. 
TABLE 3: Male students after teaching.

\begin{tabular}{|c|c|c|c|c|c|c|c|}
\hline Teaching methods & Class & Creative thinking & Learning attitude & Learning ability & Basic ability & Painting & $\begin{array}{c}\text { Cultural } \\
\text { lessons }\end{array}$ \\
\hline \multirow{2}{*}{ Offline teaching } & Class 1 & 2.46 & 2.19 & 2.34 & 2.16 & 2.11 & 1.95 \\
\hline & Class 2 & 2.26 & 2.3 & 1.8 & 2.09 & 2.28 & 2.16 \\
\hline \multirow{2}{*}{ General online teaching } & Class 3 & 3.79 & 4.07 & 3.84 & 3.9 & 4.05 & 4.46 \\
\hline & Class 4 & 4.34 & 4.97 & 4.21 & 4.3 & 4.22 & 4.81 \\
\hline \multirow{2}{*}{ Virtual simulation online teaching } & Class 5 & 6.08 & 5.93 & 6.23 & 6.28 & 6.13 & 6.12 \\
\hline & Class 6 & 6.56 & 6.4 & 6.51 & 6.81 & 6.92 & 6.91 \\
\hline
\end{tabular}

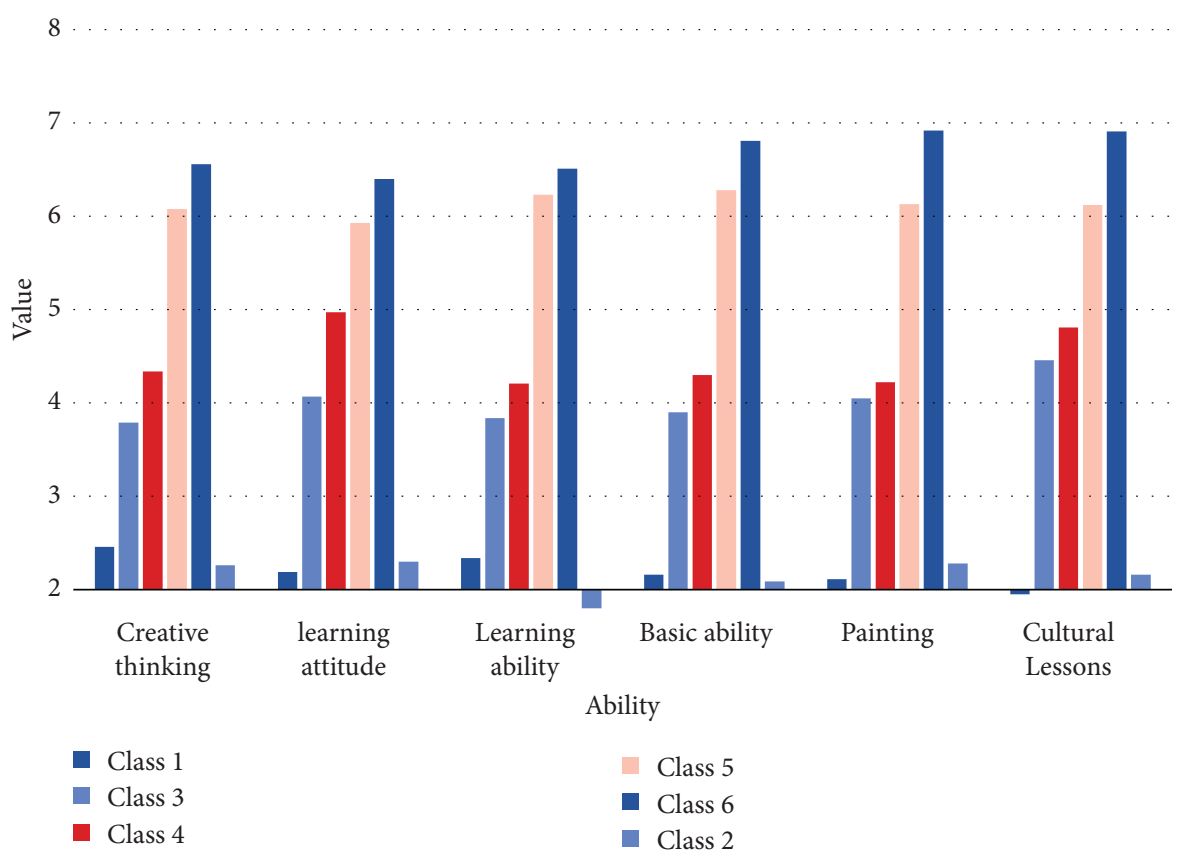

FIgURE 4: Changes of male students after teaching.

TABLE 4: Changes of female students after teaching.

\begin{tabular}{|c|c|c|c|c|c|c|c|}
\hline Teaching methods & Class & Creative thinking & Learning attitude & Learning ability & Basic ability & Painting & $\begin{array}{c}\text { Cultural } \\
\text { lessons }\end{array}$ \\
\hline \multirow{2}{*}{ Offline teaching } & Class 1 & 2.45 & 2.59 & 2.44 & 2.3 & 2.98 & 2.71 \\
\hline & Class 2 & 3.13 & 2.95 & 2.99 & 3 & 3.44 & 3.37 \\
\hline \multirow{2}{*}{ General online teaching } & Class 3 & 4.34 & 4.46 & 4.55 & 4.95 & 4.36 & 4.61 \\
\hline & Class 4 & 4.76 & 5.32 & 5.21 & 5.26 & 4.93 & 4.74 \\
\hline \multirow{2}{*}{ Virtual simulation online teaching } & Class 5 & 5.85 & 6.02 & 6.02 & 6.25 & 6.04 & 6.16 \\
\hline & Class 6 & 6.36 & 6.96 & 6.44 & 6.99 & 6.31 & 6.45 \\
\hline
\end{tabular}

virtual reality teaching, the average has increased to about 6.2 , which is higher than that of male students.

4.3. Survey of Teaching Views. After the completion of the unit assignment, the students' understanding of the unit course content is surveyed and compared. The survey results are shown in Table 5.

It can be seen that before teaching, most students have relatively little knowledge about stage art, singing, and other related arts. How many students only stay at the stage of having a little understanding without comparing the teaching results is as shown in Figure 6.

It can be seen from Figure 6 that after virtual reality teaching, students' understanding of various arts has been greatly improved.

In order to understand the degree of student satisfaction with different teaching methods, we conducted a survey of students with different teaching methods, as shown in Table 6. 


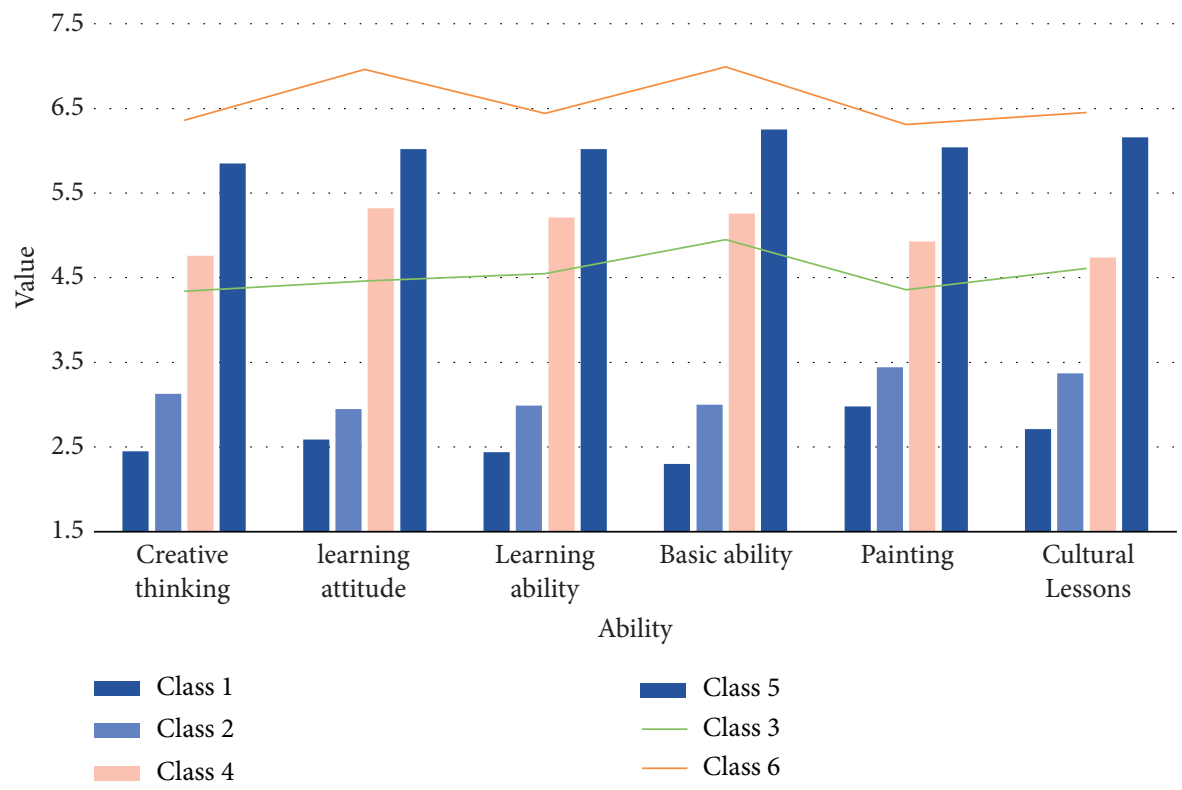

Figure 5: Female students after teaching.

TABLE 5: Level of understanding before teaching.

\begin{tabular}{lcccc}
\hline & Very understanding & To understanding & Basic understanding & Do not know \\
\hline Choreography & 2 & 4 & 5 & 105 \\
Singing & 2 & 8 & 18 & 101 \\
Facebook & 1 & 8 & 21 & 99 \\
Business & 0 & 3 & 13 & 92 \\
Character & 5 & 26 & 52 & 39 \\
\hline
\end{tabular}

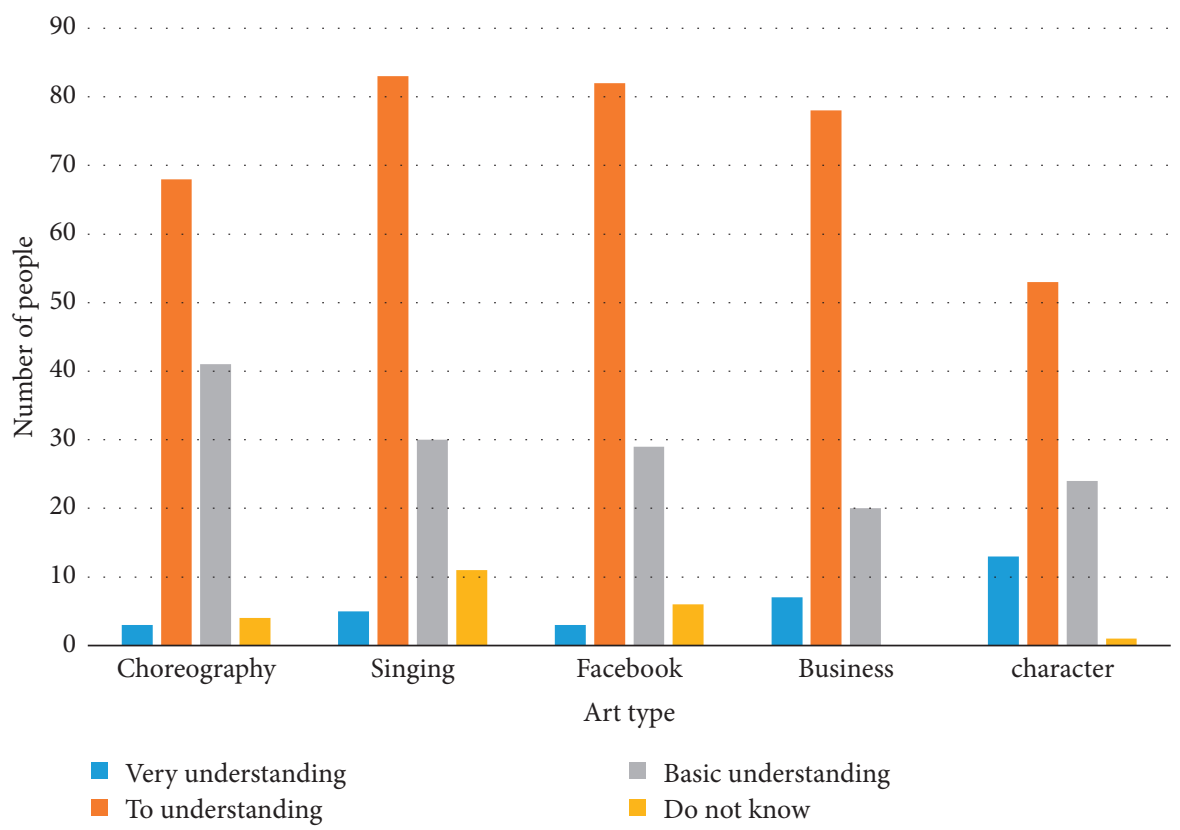

Figure 6: Degree of understanding after teaching. 
TABle 6: Traditional teaching satisfaction.

\begin{tabular}{lcccccc}
\hline & Very dissatisfied & Not satisfied & General & Okay & Satisfaction & Very satisfied \\
\hline Class 1 & 5 & 10 & 18 & 15 & 9 & 6 \\
Class 2 & 11 & 5 & 12 & 18 & 15 & 15 \\
Class 3 & 7 & 5 & 23 & 21 & 13 & 6 \\
Class 4 & 4 & 7 & 22 & 19 & 18 & 12 \\
Class 5 & 2 & 4 & 17 & 12 & 21 & 10 \\
Class 6 & 5 & 3 & & & 15 \\
\hline
\end{tabular}

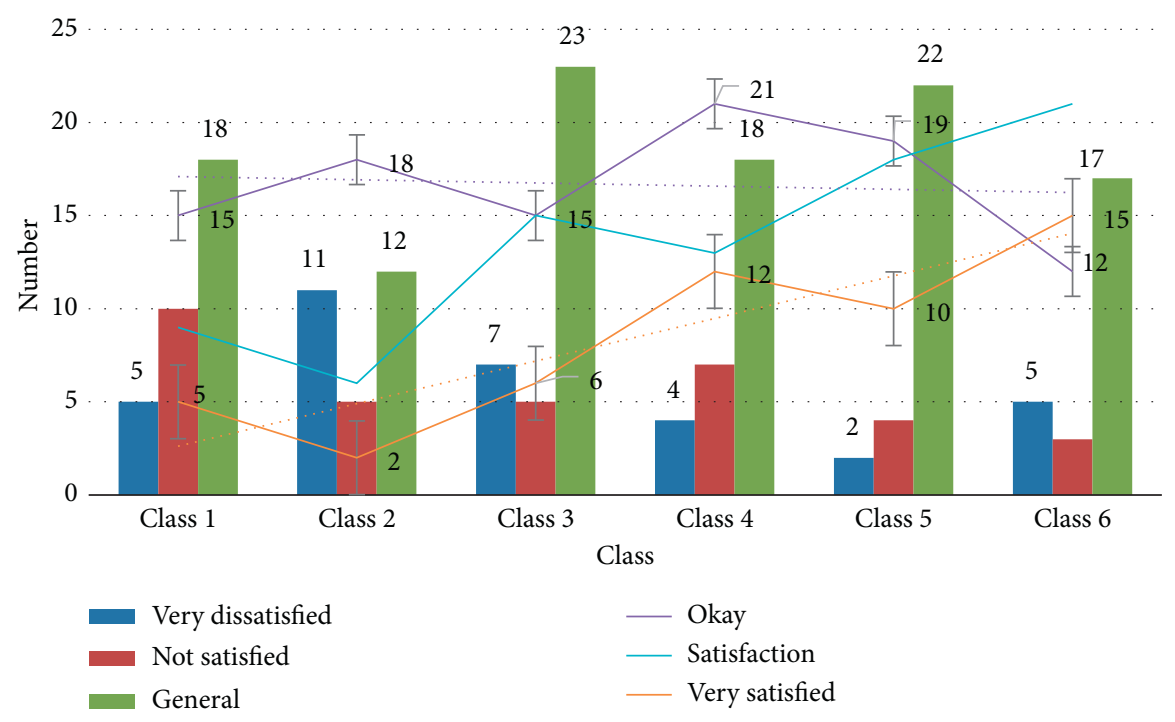

FIgURE 7: Traditional teaching satisfaction survey.

As can be seen from Figure 7, in the online English teaching virtual reality, overall, the number of people who are satisfied with the method in this paper accounts for about $60 \%$, while the traditional teaching method only accounts for about $30 \%$.

\section{Conclusion}

The unique data of the education system include not only the conversation data generated by teacher-student interaction, but also the education management data of online student management.

It is also beneficial to let students play a leading role and encourage independent student learning. Students can choose appropriate courses.

The artificial intelligence in education has brought new vitality to traditional school education. In the future, schools will shift from a large-scale teaching model to more innovative and student-centered personalized teaching. With the support of artificial intelligence technology, it may be possible to truly realize the educational ideals of personalized education.

\section{Data Availability}

No data were used to support this study.

\section{Conflicts of Interest}

The authors declare that there are no conflicts of interest in this paper.

\section{Authors' Contributions}

All authors have seen the manuscript and approved to submit to your journal.

\section{Acknowledgments}

This work was supported by the Scientific Research Program Funded by the Scientific Research Foundation of Xijing University (Grant No. XJ180113) and the Teaching and Reform Program of Xijing University (Grant No. JGYB2133).

\section{References}

[1] Y. Guo, "Research on the hierarchical teaching of higher vocational mathematics," Farm Staff, vol. 576, no. 5, p. 180, 2018.

[2] W. Lu and Y. Sheng, "Research on the online teaching management model of higher vocational colleges under the background of "suspension of classes and non-stop schools"," International Public Relations, vol. 102, no. 6, pp. 122-123, 2020. 
[3] K. Y. Chau, K. M. Y. Law, and Y. M. Tang, "Impact of selfdirected learning and educational technology readiness on synchronous E-learning," Journal of Organizational and End User Computing, vol. 33, no. 6, pp. 1-20, 2021.

[4] S. Unger and W. Meiran, "Student attitudes towards online education during the COVID-19 viral outbreak of 2020: distance learning in a time of social distance," International Journal of Technology in Education and Science, vol. 4, no. 4, pp. 256-266, 2020.

[5] L. Zhang, "A brief analysis of piano teaching practice," Shaanxi Education (Higher Education), vol. 5, p. 76+82, 2020.

[6] J. Wen, X. Wei, T. He, and S. Zhang, "Regression analysis on the influencing factors of the acceptance of online education platform among college students," Ingénierie des Systèmes d'Information, vol. 25, no. 5, pp. 595-600, 2020.

[7] M. Donadel, "Online education and the feeling of (dis)embodiment: a somatic perspective of a learning experience," Journal of Dance \& Somatic Practices, vol. 12, no. 1, pp. 155-161, 2020.

[8] G. Basilaia and D. Kvavadze, "Transition to online education in schools during a SARS-COVID-19 COVID-19 (COVID19) pandemic in Georgia," Pedagogical Research, vol. 5, no. 4, pp. 1-9, 2020.

[9] R. Vella, "Becoming the middle sea: portraits of the mediterranean in art education," International Journal of Education Through Art, vol. 12, no. 1, pp. 109-122, 2016.

[10] A. Simpson, F. H. Farley, and R. W. Neperud, "The foundations of aesthetics, art and art education," Studies in Art Education, vol. 32, no. 2, pp. 120-123, 2018.

[11] H. Zhang, "Persist in quality and adapt to challenges-also on online art education," Art Education, vol. 358, no. 6, pp. 13-16, 2020.

[12] Z. Lv, X. Li, and W. Li, "Virtual reality geographical interactive scene semantics research for immersive geography learning," Neurocomputing, vol. 254, pp. 71-78, 2017.

[13] H. Fan and Y. Xu, "Reflections on the questionnaire survey on online teaching of art education under the background of the prevention and control of the new crown epidemic," Shenhua (II), vol. 939, no. 12, pp. 79-80, 2020.

[14] W. Zhou, "The development of Tibetan social art education under the current "Internet +" boom," Journal of Tibet University: Social Science Edition, vol. 1, pp. 185-190, 2020.

[15] T. Liu, "The construction of an online training platform for art design talents under the background of the Internet age: a review of "virtual space: art design and education in the information age"," Chinese Journal of Education, vol. 311, no. 3, pp. 130-132, 2019.

[16] X.. Li, "“Changes" and "unchanging" in online teaching of art majors in the epidemic era," Art Education, vol. 358, no. 6, pp. 17-20, 2020.

[17] R. Ding, "Thoughts on the standardization and construction of online music education," Art Education, vol. 357, no. 5, pp. 57-60, 2020.

[18] S. Zhang, W. Tan, Q. Wang, and W. Nan, "A new method of online extreme learning machine based on hybrid kernel function," Neural Computing and Applications, vol. 31, no. 4, 2019.

[19] H. Gao and F. Li, "The breakthrough path and prospect of online teaching of art majors in the post-epidemic era," Art Education, vol. 358, no. 6, pp. 21-24, 2020.

[20] H. Zhang, "The exploration of the third-line interactive cloud curriculum for the teaching method courses of normal majors-_taking "Preschool Children's Art Education" as an example," Journal of Chifeng University (Natural Science Edition), vol. 036, no. 005, pp. 12-14, 2020.

[21] H. Wang, "Research on the reform of mixed teaching mode in art education under the background of internet + -taking jiangsu maritime vocational and technical college as an example," Authors Tiandi, vol. 558, no. 24, p. 192+194, 2020.

[22] R. Song, "Innovative thinking and practice of online aesthetic education during the epidemic period based on the OBE concept," Art Education, vol. 358, no. 6, pp. 225-228, 2020.

[23] Y. Bai, "Exploration of the training mode of art design major based on online class-taking "logo design" course as an example," Hunan Packaging, vol. 35, no. 5, pp. 163-166, 2020.

[24] X. Chen, "Analysis of the current situation of the communication of humanities and art science under the new media ecology," News \& Communication, vol. 350, no. 5, pp. 58-59, 2019.

[25] X. Niu and Y. Yin, “Teachers' learning moves towards a creative ecology-taking preschool teachers' art education classroom teaching reform as an example," Journal of Shaanxi Preschool Teachers College, vol. 34, no. 11, pp. 7-10, 2018. 